\title{
Efek pemberian ekstrak teh hijau (Camellia sinesis (L) O. Kuntze) var. Assamica terhadap total lemak tubuh dan profil lipid wanita dewasa overweight dan obesitas
}

Effect of green tea (Camellia sinensis (L.) O. Kuntze) var Assamica extract supplementation to body fat total and lipid profile of overweight and obese adult women

Ernawati Hardani ${ }^{1}$, Wiryatun Lestariana ${ }^{2}$, Susetyowati ${ }^{3}$

\begin{abstract}
Background: Overweight and obesity can cause high body fat total and lipid profile in the blood that bring risk for diseases to the bearer. Some studies on green tea extract supplementation have been undertaken to find out its effect to fat reduction in children, men, and mice and the result showed reduction in body fat, weight, appetite, and triglyceride level. This study uses green tea extract supplemented to overweight and obese women. Objective: To find out the reduction of body fat total and lipid profile (total cholesterol, triglyceride, $L D L, H D L$ ) in the blood of overweight and obese women personnel of Yogyakarta Municipal Health Office supplemented with green tea extract. Method: The study was randomized double blinded control trial. Subject of the study were overweight and obese women of 3555 years old personnel of Yogyakarta Municipal Health Office. Samples were 86 women randomly taken, comprising experiment group and control group, each of which consisting of 43 women. Each group had diet according to individual appetite. Both groups were given capsules of similar form and color but different ingredients: placebo and green tea extract. The experiment took three months. Blood was taken before and after the experiment to identify lipid profile (total cholesterol, triglyceride, LDL, HDL). Body fat total was examined using body fat analyzer. Data analysis used paired t-test. Results: Green tea extract supplementation could significantly reduce body fat total and insignificantly reduce cholesterol level, triglyceride and LDL, significantly increase HDL in overweight and obese women. Conclusion: Green tea extract supplementation could reduce body fat total and increase HDL $(p<0.005)$.
\end{abstract}

KEY WORDS: overweight women, obese women, green tea extract, body fat total, lipid profile, LDL, HDL, triglyceride, cholesterol

\begin{abstract}
ABSTRAK
Latar belakang: Overweight dan obesitas dapat menyebabkan total lemak tubuh (TLT) dan profil lipid dalam darah tinggi sehingga penyandangnya rawan penyakit. Beberapa penelitian telah dilakukan dengan memberikan ekstrak teh hijau untuk mengetahui pengaruhnya terhadap reduksi lemak pada anak-anak, laki-laki, serta tikus galur wistar dan hasilnya menunjukkan adanya penurunan lemak tubuh, berat badan, nafsu makan, dan kadar trigliserida. Penelitian ini menggunakan ekstrak teh hijau yang diberikan pada wanita yang mengalami overweight dan obesitas. Tujuan: Mengkaji ada atau tidaknya penurunan TLT dan profil lipid (kolesterol total, trigliserida, LDL, HDL) dalam darah pada wanita dewasa yang overweight dan obesitas pegawai Dinas Kesehatan Kota Yogyakarta yang diberikan ekstrak teh hijau. Metode: Penelitian eksperimental dengan randomized control trial (RCT) menggunakan double blind. Subjeknya adalah wanita usia 35-55 tahun yang overweight dan obesitas, diperoleh dari pegawai Dinas Kesehatan Kota Yogyakarta. Sampel dipilih secara acak 86 wanita (43 perlakuan dan 43 kontrol). Masing-masing kelompok makannya sesuai selera individu ad libitum. Kelompok perlakuan dan kontrol diberi kapsul selama 3 bulan dengan bentuk dan warna yang sama tetapi isinya berbeda (placebo dan ekstrak teh hijau). Darah diambil sebelum dan sesudah penelitian untuk pemeriksaan profil lipid dan TLT menggunakan body fat analyzer. Hasil yang diperoleh dianalisis dengan menggunakan paired t-test. Hasil: Penelitian ini membuktikan pemberian ekstrak teh hijau dapat menurunkan secara signifikan TLT; menurunkan kadar kolesterol, trigliserida (TGL), dan low density lipoprotein (LDL) tetapi tidak signifikan; serta menaikkan secara signifikan kadar high density lipoprotein (HDL) pada wanita dewasa overweight dan obesitas. Simpulan: Pemberian ekstrak teh hijau dapat menurunkan TLT dan meningkatkan HDL $(\mathrm{p}<0,005)$.
\end{abstract}

KATA KUNCI: wanita overweight dan obesitas, ekstrak teh hijau, total lemak tubuh, profil lipid (kolesterol total, trigliserida, LDL, dan HDL)

\footnotetext{
Korespondensi: Dinas Kesehatan Kota Yogyakarta (Puskesmas Jetis Kota Yogyakarta), Jl. Diponegoro 91, Yogyakarta, e-mail: r12rna@gmail.com ${ }^{2}$ Bagian Biokimia, Fakultas Kedokteran Universitas Gadjah Mada, Jl. Farmako, Sekip Utara, Yogyakarta 55281

${ }^{3}$ Program Studi Gizi Kesehatan, Fakultas Kedokteran Universitas Gadjah Mada, Jl. Farmako, Sekip Utara, Yogyakarta 55281
} 


\section{PENDAHULUAN}

Prevalensi obesitas semakin meningkat, hampir setengah milyar penduduk dunia saat ini tergolong overweight atau obese (1). Menurut data Riset Kesehatan Dasar (Riskedas) tahun 2007, di Indonesia prevalensi nasional obesitas secara umum pada penduduk berusia lebih dari 15 tahun adalah 19,1\%, dengan prevalensi lakilaki 13,9\% sedangkan perempuan 23,8\% serta prevalensi obesitas berdasarkan IMT sebesar 10,3\% (2). Studi di Amerika Serikat memperlihatkan bahwa untuk setiap $10 \%$ kenaikan berat badan (BB) terjadi peningkatan plasma kolesterol sebesar $12 \mathrm{mg} / \mathrm{dL}$. Dari data National Health and Nutrition Examination Survey (NHANES) juga ditemukan bahwa risiko hiperkolesterolemia (serum kolesterol $250 \mathrm{mg} / \mathrm{dL}$ ) pada orang Amerika yang overweight adalah 1,5 kali lebih besar dibandingkan pada individu normal usia 20 sampai 74 tahun $(3,4)$.

Berbagai cara penanganan overweight dan obesitas telah banyak diteliti dan dilaksanakan, antara lain melalui perubahan gaya hidup, aktivitas fisik, pengaturan pola makan (diet), obatan-obatan, operasi, dan pengobatan alternatif dengan cara tradisional maupun herbal. Saat ini pengobatan secara herbal lebih banyak diminati masyarakat karena tidak ada efek samping dan biayanya relatif murah. Termasuk dalam urusan penanganan overweight dan obesitas. Pemilihan teh hijau dalam penelitian ini didasari oleh adanya keyakinan empiris di masyarakat bahwa teh hijau (Camellia sinensis, (L.) O. Kuntze var. Assamica) mampu menurunkan berat badan dan kadar lemak (5); tradisi minum teh telah menjadi kebiasaan masyarakat dan teh dikenal luas; teh hijau relatif murah dan mudah didapatkan; serta teh hijau merupakan teh yang paling alami dan belum mengalami proses perubahan (6).

Beberapa penelitian yang mendukung manfaat teh hijau untuk penurunan total lemak tubuh dan perubahan profil lipid adalah penelitian di Jepang (7) yaitu penurunan lemak tubuh $(3,7 \%)$, berat badan $(1,5 \%)$, dan body mass index atau BMI (1,5\%) pada laki-laki sehat berusia 2446 tahun. Selain itu, hasil penelitian pada hewan coba juga membuktikan bahwa pemberian ekstrak teh hijau dapat menurunkan berat badan dan nafsu makan, serta penurunan trigliserida pada tikus jantan galur wistar (6). Penelitian ini bertujuan untuk mengkaji pengaruh pemberian ekstrak teh hijau terhadap penurunan total lemak tubuh (TLT) dan profil lipid (kolesterol total, trigliserida, LDL, dan HDL) pada wanita dewasa pegawai Dinas Kesehatan Kota Yogyakarta yang overweight dan obesitas.

\section{BAHAN DAN METODE}

Penelitian ini merupakan penelitian eksperimental dengan rancangan penelitian randomized control trial (RCT) menggunakan double blind. Pemberian kode dilakukan oleh apoteker yang bertugas mempersiapkan kapsul. Peneliti baru mengetahui kode setelah tahap analisis data selesai dilakukan. Kelompok perlakuan diberikan kapsul ekstrak teh hijau satu kali sehari sedangkan kelompok kontrol diberikan kapsul plasebo satu kali sehari selama 90 hari. Penelitian ini dilaksanakan di Dinas Kesehatan Kota Yogyakarta pada bulan MaretJuni 2010.

Populasi penelitian adalah wanita overweight dan obesitas yang bekerja di Puskesmas di bawah Dinas Kesehatan Kota Yogyakarta yaitu sebanyak 86 orang; 43 untuk perlakuan (diberikan ekstrak teh hijau) dan 43 untuk kontrol (diberikan ekstrak jagung, plasebo nongluten). Ekstrak teh hijau adalah kapsul berisi ekstrak teh hijau yang mengandung 242,5 $\pm 4 \mathrm{mg}$ polyphenols dan 161,7 $\pm 1,7 \mathrm{mg}$ epigallocatechin gallate (EGCG). Sementara itu, plasebo adalah kapsul yang berisi tepung jagung nongluten dengan komposisi $576 \pm 3,3 \mathrm{mg}$. Plasebo nongluten ini dipilih karena sifatnya yang netral, tidak ada pengaruhnya terhadap kinerja dan metabolisme tubuh, khususnya dalam hal penurunan TLT dan perubahan profil lipid. Observasi dilakukan pada kedua kelompok sebanyak 6 kali selama penelitian setiap 2 minggu sekali bersamaan dengan pembagian kapsul dan recall 24 jam. Pemilihan hari untuk mengetahui data konsumsi makanan dengan recall 24 jam adalah 6 kali yaitu 4 kali diambil pada hari kerja dan 2 hari diambil pada akhir pekan. Pada akhir penelitian, yaitu minggu ke-12 (hari ke-90) dilakukan pengukuran TLT dan profil lipid.

Dari populasi penelitian dipilih subjek penelitian, yaitu mereka yang memenuhi kriteria overweight $\left(\mathrm{IMT}=25-27 \mathrm{~kg} / \mathrm{m}^{2}\right.$ ) atau obesitas (IMT $\left.>27 \mathrm{~kg} / \mathrm{m}^{2}\right)(2)$, serta memenuhi kriteria inklusi maupun eksklusi. Kriteria 
inklusinya yaitu usia 35-55 tahun; tidak menderita penyakit kronis (hipertensi, penyakit jantung, penyakit hati, dan penyakit ginjal) sebelum penelitian dilakukan; tidak sedang mengonsumsi obat-obatan dan suplemen (penurun berat badan, penurun kolesterol, penambah hormon, obat diuretik) sekurang-sekurangnya 2 minggu sebelum penelitian; tidak sedang menjalani program diet; dan bersedia mengikuti penelitian dengan menandatangani informed consent. Apabila hasil pemeriksaan di laboratorium terhadap TLT dan profil lipid, salah satu saja hasilnya tergolong tinggi, maka responden sudah dapat dimasukkan dalam sampel penelitian. Kriteria eksklusinya adalah instruktur senam dan atlet; merokok dan mengonsumsi alkohol; mengonsumsi teh hijau atau ekstrak teh hijau secara rutin.

Jumlah sampel yang akan digunakan berdasarkan rumus besar sampel (8) dengan tingkat kepercayaan 95\%; power $90 \%$; dan selisih kelompok perlakuan dengan kelompok kontrol ( $\mu 1-\mu 2)$ sebesar 0,11 ; dan standar deviasinya $(\sigma)$ adalah 0,15 (7). Berdasarkan perhitungan jumlah sampel tersebut maka jumlah sampel minimal sebesar 39 orang untuk setiap kelompok dan untuk mengantisipasi sampel yang luput dari pengamatan (drop $o u t)$ maka jumlah sampel ditambah $10 \%$ sehingga jumlah sampel yang diperlukan adalah 43 orang untuk setiap kelompok. Sampel yang sudah diperoleh dirandom untuk masuk kelompok perlakuan dan kontrol.

Variabel yang akan diteliti dalam penelitian ini adalah variabel independen berupa pemberian ekstrak teh hijau. Variabel dependennya adalah perubahan TLT dan perubahan profil lipid. Variabel terkontrol adalah umur, jenis kelamin, pekerjaan, dan gaya hidup. Variabel yang diduga confounding adalah aktivitas, penggunaan alat kontrasepsi, dan asupan zat gizi berupa lemak dan karbohidrat. Variabel ini tidak memasukkan kondisi responden bila di tengah penelitian terjadi serangan penyakit kronis.

Total lemak tubuh (TLT) adalah jumlah lemak yang terkandung dalam seluruh tubuh (dalam satuan persen) yang dikelompokkan dalam kategori normal (TLT $\leq 25 \%$ untuk laki-laki; $\leq 30 \%$ untuk perempuan) dan lemak berlebih (TLT $>25 \%$ untuk laki-laki; > 30\% untuk perempuan). Profil lipid adalah hasil pemeriksaan kadar lipid dalam darah yang terdiri dari kolesterol total, trigliserida, kolesterol LDL, dan kolesterol HDL yang dikategorikan tidak normal bila kadar kolesterol total lebih dari atau sama dengan $200 \mathrm{mg} / \mathrm{dL}$; dan atau kadar trigliserida lebih dari atau sama dengan $150 \mathrm{mg} / \mathrm{dL}$; dan atau kadar kolesterol LDL lebih dari atau sama dengan $130 \mathrm{mg} / \mathrm{dL}$; dan atau kadar kolesterol HDL kurang dari atau sama dengan $40 \mathrm{mg} / \mathrm{dL}$. Total lemak tubuh diperoleh dari hasil pengukuran menggunakan body fat analyzer merek Omron. Data profil lipid dilakukan dengan pengambilan sampel darah $2 \mathrm{cc}$ yang dimasukkan ke dalam tabung blood vein vaccum-venoject dan diperiksa dengan fotometer Microlab 300. Sebelum pengambilan sampel darah, responden diwajibkan puasa selama 10 jam. Pemeriksaan sampel darah dilakukan di laboratorium Puskesmas Jetis Yogyakarta (sudah berstandar ISO).

Data tentang obesitas dan overweight dikumpulkan dengan cara melakukan pengukuran antropometri menggunakan alat timbangan injak merek Electronic Personal Scale dengan ketelitian $0,1 \mathrm{~kg}$. Sementara itu, tinggi badan diukur dengan alat ukur microtoise kapasitas panjang $200 \mathrm{~cm}$ dengan ketelitian $0,1 \mathrm{~cm}$. Hasil pengukuran berat dan tinggi badan merupakan rerata dari 3 kali pengukuran. Indeks massa tubuh (IMT) dihitung berdasarkan rumus berat badan $(\mathrm{kg}$ ) dibagi hasil kuadrat tinggi badan (m). Data konsumsi makanan yang diperoleh dengan multiple recall 24 jam kemudian dikategorikan berdasarkan angka kecukupan gizi (AKG) normal yang diperlukan per orang per hari yaitu energi $1800 \mathrm{kkal} /$ hari; protein $32 \mathrm{~g} /$ hari; lemak $60 \mathrm{~g}$ /hari; karbohidrat $243 \mathrm{~g} /$ hari; serat $25 \mathrm{~g}$ /hari; dan kolesterol $30 \mathrm{~g} /$ hari. Pola hidup dan kondisi kesehatan ditanyakan dengan kuesioner penelitian.

Selanjutnya, data aktivitas fisik adalah aktivitas mayoritas yang dilakukan di kantor dan banyaknya olahraga yang dilakukan dalam 1 minggu. Aktivitas berat jika aktivitas kantor mayoritas berdiri dan berjalan serta berolahraga lebih dari 1 kali dalam seminggu. Aktivitas ringan jika aktivitas kantor mayoritas duduk serta berolah raga 1 kali atau kurang dalam seminggu. Alat kontrasepsi dikategorikan hormonal jika berupa pil KB, susuk/implan, suntik KB sedangkan dikategorikan non-hormonal jika berupa IUD, steril, dan kondom. Pengumpulan data dibantu oleh tenaga enumerator yaitu 2 orang perawat dan 2 orang analis kesehatan yang telah diseleksi dan dilatih sebelum penelitian. 
Analisis data berupa analisis bivariabel antara variabel independen dan variabel dependen menggunakan uji paired t-test untuk menguji ada tidaknya TLT dan perubahan profil lipid setelah penderita overweight dan obesitas mendapatkan pemberian ekstrak teh hijau. Penelitian ini telah memperoleh ethical clearance dari Komisi Etik Fakultas Kedokteran Universitas Gadjah Mada.

\section{HASIL}

\section{Karakteristik subjek}

Berdasarkan Tabel 1 diketahui bahwa sebagian besar subjek berusia 35-45 tahun baik pada kelompok perlakuan $(62,8 \%)$ maupun kelompok kontrol $(51,2 \%)$. Sementara itu, sebagian besar subjek pada kelompok perlakuan memiliki aktivitas fisik berat $(55,8 \%)$ sedangkan kelompok kontrol memiliki aktivitas fisik ringan $(58,1 \%)$. Berdasarkan penggunaan kontrasepsi, jenis nonhormon paling banyak digunakan oleh subjek pada kelompok perlakuan $(51,2 \%)$ sedangkan subjek kontrol terbanyak menggunakan kontrasepsi jenis hormon $(79,1 \%)$.

Tabel 2 menjelaskan karakteristik subjek berdasarkan jumlah asupan energi, protein, lemak, karbohidrat, serat, dan kolesterol. Berdasarkan tabel tersebut terlihat bahwa asupan subjek pada kelompok perlakuan dan kontrol sebagian besar masih tergolong kurang dari AKG yang dianjurkan kecuali untuk asupan kolesterol. Sebagian besar subjek pada kelompok perlakuan memiliki asupan kolesterol lebih dari 30 gram per hari $(51,2 \%)$. Sebaliknya, asupan kolesterol pada kelompok kontrol sebagian besar tergolong kurang dari 30 gram per hari $(76,7 \%)$. Berdasarkan uji yang telah dilakukan terhadap variabel-variabel pada Tabel 1 dan 2, tidak menunjukkan adanya perbedaan yang signifikan secara statistik antara kelompok perlakuan dan kelompok kontrol, kecuali pada variabel kontrasepsi dan asupan kolesterol $(\mathrm{p}<0,05)$. Kondisi ini menunjukkan kondisi awal subjek pada kelompok kontrol tidak berbeda nyata atau hampir sama (homogen) dengan kondisi subjek pada kelompok perlakuan.

Selanjutnya, asupan makan subjek diketahui dengan recall yang dilakukan sebanyak 6 kali setiap
Tabel 1. Distribusi karakteristik demografi

\begin{tabular}{lccc}
\hline \multirow{2}{*}{ Variabel } & \multicolumn{2}{c}{ Kelompok } & \multirow{2}{*}{$\mathbf{p}$} \\
\cline { 2 - 3 } & $\begin{array}{c}\text { Perlakuan } \\
\mathbf{n}=\mathbf{4 3}(\mathbf{\%})\end{array}$ & $\begin{array}{c}\text { Kontrol } \\
\mathbf{n}=\mathbf{4 3}(\mathbf{\%})\end{array}$ & \\
\hline Usia (tahun) & & & \\
$\quad 35-45$ & $27(62,8 \%)$ & $22(51,2 \%)$ & 0,38 \\
$46-55$ & $16(37,2 \%)$ & $21(48,8 \%)$ & \\
Aktivitas fisik & & & \\
$\quad$ Ringan & $19(44,2 \%)$ & $25(58,1 \%)$ & 0,28 \\
$\quad$ Berat & $24(55,8 \%)$ & $18(41,9 \%)$ & \\
Kontrasepsi & & & \\
$\quad$ Non hormon & $22(51,2 \%)$ & $9(20,9 \%)$ & $0,01^{*}$ \\
$\quad$ Hormon & $21(48,8 \%)$ & $34(79,1 \%)$ & \\
\hline
\end{tabular}

Tabel 2. Distribusi karakteristik asupan subjek

\begin{tabular}{|c|c|c|c|}
\hline \multirow[b]{2}{*}{ Variabel } & \multicolumn{2}{|c|}{ Kelompok } & \multirow[b]{2}{*}{$\mathbf{p}$} \\
\hline & $\begin{array}{l}\text { Perlakuan } \\
n=43(\%)\end{array}$ & $\begin{array}{c}\text { Kontrol } \\
n=43(\%)\end{array}$ & \\
\hline $\begin{array}{l}\text { Energi } \\
\begin{array}{l}(100 \% \mathrm{AKG} \text { energi) } \\
\leq 1800 \mathrm{kcal} / \mathrm{hr} \\
\geq 1800 \mathrm{kcal} / \mathrm{hr}\end{array}\end{array}$ & $\begin{array}{c}38(88,4) \\
5(11,6)\end{array}$ & $\begin{array}{c}36(83,7) \\
7(16,3)\end{array}$ & 0,75 \\
\hline $\begin{array}{l}\text { Protein } \\
\begin{array}{l}\text { (10\% AKG energi) } \\
\quad \leq 32 \mathrm{~g} / \mathrm{hr} \\
\quad \geq 32 \mathrm{~g} / \mathrm{hr}\end{array}\end{array}$ & $\begin{array}{l}33(76,7) \\
10(23,3)\end{array}$ & $\begin{array}{l}28(65,1) \\
15(34,9)\end{array}$ & 0,34 \\
\hline $\begin{array}{l}\text { Lemak } \\
\begin{array}{l}\text { (30\% AKG energi) } \\
\quad \leq 60 \mathrm{~g} / \mathrm{hr} \\
\geq 60 \mathrm{~g} / \mathrm{hr}\end{array}\end{array}$ & $\begin{array}{c}39(90,7) \\
4(9,3)\end{array}$ & $\begin{array}{c}41(95,3) \\
2(4,7)\end{array}$ & 0,67 \\
\hline $\begin{array}{l}\text { Karbohidrat } \\
\begin{array}{l}(60 \% \text { AKG energi) } \\
\leq 243 \mathrm{~g} / \mathrm{hr} \\
\quad \geq 243 \mathrm{~g} / \mathrm{hr}\end{array}\end{array}$ & $\begin{array}{l}31(72,1) \\
12(27,9)\end{array}$ & $\begin{array}{l}24(55,8) \\
19(44,2)\end{array}$ & 0,17 \\
\hline $\begin{array}{l}\text { Serat } \\
\qquad \leq 25 \mathrm{~g} / \mathrm{hr} \\
\quad \geq 25 \mathrm{~g} / \mathrm{hr}\end{array}$ & $\begin{array}{c}35(81,4) \\
8(18,6)\end{array}$ & $\begin{array}{l}30(69,8) \\
13(30,2)\end{array}$ & 0,31 \\
\hline $\begin{array}{l}\text { Kolesterol } \\
\quad \leq 30 \mathrm{~g} / \mathrm{hr} \\
\geq 30 \mathrm{~g} / \mathrm{hr} \\
\end{array}$ & $\begin{array}{l}21(48,8) \\
22(51,2)\end{array}$ & $\begin{array}{l}33(76,7) \\
10(23,3)\end{array}$ & $0,01^{*}$ \\
\hline
\end{tabular}

Keterangan:* signifikan $(\mathrm{p}<0,05)$;

$\mathrm{AKG}=$ angka kecukupan gizi; $\mathrm{hr}=$ hari

2 minggu sekali ( 3 kali di awal penelitian dan 3 kali di akhir penelitian). Jika diperhatikan dari hasil pada Tabel 3, berdasarkan t-test menunjukkan tidak terdapat perbedaan yang signifikan $(p>0,05)$ antara rerata asupan zat gizi pada awal penelitan dengan rerata asupan zat gizi pada akhir penelitian. Selain itu, berdasarkan hasil wawancara juga diketahui bahwa kepatuhan subjek dalam mengonsumsi kapsul 
Tabel 3. Rerata asupan zat gizi awal penelitian dan akhir penelitian pada kelompok perlakuan dan kelompok kontrol

\begin{tabular}{lccc}
\hline \multicolumn{1}{c}{ Variabel } & Awal & Akhir & p \\
\hline Energi (kkal) & & & \\
$\quad$ Perlakuan & $1452,4 \pm 353,3$ & $1436,5 \pm 362,6$ & 0,215 \\
$\quad$ Kontrol & $1325,8 \pm 322,7$ & $1335,7 \pm 318,5$ & 0,657 \\
Protein (g) & & & \\
$\quad$ Perlakuan & $45 \pm 10$ & $45,2 \pm 13,5$ & 0,701 \\
$\quad$ Kontrol & $46 \pm 14$ & $44,3 \pm 11,9$ & 0,192 \\
Lemak (g) & & & \\
$\quad$ Perlakuan & $42,3 \pm 13,6$ & $47,5 \pm 14,4$ & 0,182 \\
$\quad$ Kontrol & $46,1 \pm 14,8$ & $52,9 \pm 13,7$ & 0,112 \\
Karbohidrat (g) & & & \\
$\quad$ Perlakuan & $199,4 \pm 54,6$ & $219,6 \pm 54,8$ & 0,151 \\
$\quad$ Kontrol & $193,6 \pm 65,7$ & $190,1 \pm 51,6$ & 0,990 \\
Vitamin C (mg/hari) & & & \\
$\quad$ Perlakuan & $52,2 \pm 2,8$ & $53,7 \pm 2,2$ & 0,108 \\
$\quad$ Kontrol & $50,0 \pm 2,4$ & $49,7 \pm 3,0$ & 0,482 \\
Vitamin E (mg/hari) & & & \\
$\quad$ Perlakuan & $0,1 \pm 2,2$ & $0,2 \pm 2,3$ & 0,321 \\
$\quad$ Kontrol & $0,2 \pm 2,6$ & $0,4 \pm 14,8$ & 0,867 \\
Vitamin A ( $\mu$ g/hari) & & & \\
$\quad$ Perlakuan & $274,5 \pm 0,3$ & $273,4 \pm 0,3$ & 0,170 \\
$\quad$ Kontrol & $273,4 \pm 0,3$ & $272,5 \pm 0,4$ & 0,576 \\
\hline
\end{tabular}

ekstrak teh hijau maupun kapsul plasebo adalah lebih dari $80 \%$. Rerata jumlah kapsul ekstrak teh hijau dan kapsul plasebo yang dikonsumsi oleh subjek selama 90 hari adalah 73 kapsul dan rerata kapsul yang tidak dikonsumsi sebanyak 17 kapsul karena lupa atau hilang. Hal itu sudah dianggap cukup karena sudah lebih dari $80 \%$.

\section{Perubahan TLT dan profil lipid setelah perlakuan}

Setelah 90 hari penelitian, dapat dilihat hasil perbedaan profil lipid dari kelompok perlakuan dan kelompok kontrol pada Tabel 4. Profil lipid yang mengalami penurunan pada kedua kelompok adalah kolesterol, trigliserida, dan kolesterol LDL dengan hasil analisis tidak menunjukkan perubahan yang signifikan antara sebelum dan setelah perlakuan $(p>0,05)$. Sementara itu, dapat dilihat bahwa rerata hasil pengukuran TLT kelompok kontrol mengalami peningkatan sebesar $0,51 \pm 0,20 \%$. Berbeda dengan kelompok perlakuan yang mengalami penurunan sebesar $1,33 \pm 0,30 \%$. Berdasarkan hasil analisis, dapat disimpulkan bahwa ada perubahan yang signifikan kadar TLT antara sebelum dan setelah perlakuan $(\mathrm{p}<0,05)$. Demikian juga dengan kolesterol HDL yang menunjukkan perubahan signifikan antara sebelum dan setelah perlakuan $(\mathrm{p}<0,05)$. Kelompok kontrol mengalami penurunan kadar HDL sebesar $1,08 \pm 2,2 \mathrm{mg} / \mathrm{dL}$ sebaliknya kelompok perlakuan mengalami peningkatan sebesar $3,59 \mathrm{mg} / \mathrm{dL}$.

\section{BAHASAN}

\section{Karakteristik subjek penelitian}

Efek pemberian ekstrak teh hijau terhadap total lemak tubuh (TLT) dan profil lipid juga dipengaruhi oleh beberapa variabel yang berpotensi untuk mempengaruhi

Tabel 4. Perbedaan profil lipid antara sebelum dan setelah perlakuan

\begin{tabular}{lcccc}
\hline \multicolumn{1}{c}{ Variabel } & Sebelum & Sesudah & Delta & p \\
\hline TLT $(\%)$ & & & & \\
$\quad$ Kontrol & $36,63 \pm 3,60$ & $37,14 \pm 3,80$ & $0,51 \pm 0,20$ & $0,001^{*}$ \\
$\quad$ Perlakuan & $37,26 \pm 2,80$ & $35,93 \pm 3,10$ & $-1,33 \pm 0,30$ & \\
Kolesterol (mg/dL) & & & & \\
$\quad$ Kontrol & $201,04 \pm 32,00$ & $184,20 \pm 32,10$ & $-16,84 \pm 0,10$ & 0,971 \\
$\quad$ Perlakuan & $194,07 \pm 34,03$ & $176,30 \pm 34,03$ & $-17,77 \pm 0,00$ & \\
Trigliserida (mg/dL) & & & & 0,703 \\
$\quad$ Kontrol & $133,81 \pm 83,23$ & $129,46 \pm 67,70$ & $-4,35 \pm 15,53$ & \\
$\quad$ Perlakuan & $137,13 \pm 144,20$ & $133,23 \pm 112,93$ & $-3,90 \pm 31,27$ & \\
HDL (mg/dL) & & & & \\
$\quad$ Kontrol & $50,49 \pm 9,50$ & $49,41 \pm 7,30$ & $-1,08 \pm 2,20$ & $0,008^{*}$ \\
$\quad$ Perlakuan & $48,60 \pm 9,30$ & $52,19 \pm 9,30$ & $3,59 \pm 0,00$ & \\
LDL (mg/dL) & & & & \\
$\quad$ Kontrol & $109,84 \pm 29,84$ & $99,88 \pm 21,69$ & $-9,96 \pm 8,15$ & 0,398 \\
$\quad$ Perlakuan & $102,16 \pm 25,80$ & $96,90 \pm 18,80$ & $-5,26 \pm 7,00$ & \\
\hline
\end{tabular}

Keterangan: * signifikan $(\mathrm{p}<0,05) ;$ TLT $=$ total lemak tubuh;

$\mathrm{HDL}=$ high density lipoprotein $; \mathrm{LDL}=$ low density lipoprotein 
hasil penelitian. Variabel tersebut meliputi aktivitas fisik subjek, penggunaan alat kontrasepsi, kadar profil lipid (kolesterol, trigliserida, HDL, LDL) dan kadar total lemak tubuh (TLT) sebelum perlakuan serta asupan zat gizi. Asupan zat gizi berdasarkan hasil recall 24 jam sebanyak 3 kali pada awal penelitian secara statistik menunjukkan tidak terdapat perbedaan yang signifikan antara kelompok perlakuan dan kelompok kontrol. Dengan demikian, dapat dipastikan bahwa perubahan yang terjadi pada subjek setelah 90 hari penelitian bukan terjadi karena perbedaan jumlah asupan zat gizi antara kelompok perlakuan dan kelompok kontrol, tetapi karena pengaruh pemberian ekstrak teh hijau. Hal ini didukung oleh data recall sebanyak 6 kali setiap 2 minggu sekali (3 kali di awal penelitian dan 3 kali di akhir penelitian) yang menunjukkan bahwa rerata asupan zat gizi baik energi, protein, lemak, karbohidrat, vitamin $C$, vitamin E, dan vitamin A pada awal dan akhir penelitian yang tidak berbeda signifikan.

Setelah perlakuan selama 90 hari penelitian, hasilnya dapat dilihat bahwa TLT mengalami penurunan sedangkan kadar kolesterol HDL meningkat. Penurunan TLT ini dapat dipastikan karena pemberian ekstrak teh hijau sedangkan untuk peningkatan kolesterol HDL kemungkinan terjadi karena adanya kondisi subjek penelitian yang tidak dikarantina, asupan zat gizi tidak dibatasi, dan aktivitas fisiknya juga tidak dibatasi. Kondisi tersebut memungkinkan seluruh konsumsi dan asupan gizi yang diperlukan terpenuhi, termasuk keperluan antioksidan melalui vitamin $\mathrm{C}$, vitamin $\mathrm{E}$, dan vitamin A juga terpenuhi sehingga kolesterol HDL ikut meningkat.

\section{Penurunan total lemak tubuh (TLT) pada wanita dewasa overweight dan obesitas setelah perlakuan}

Hasil analisis menunjukkan bahwa terdapat penurunan yang signifikan antara pengukuran TLT sebelum dan setelah perlakuan. Hal ini menunjukkan bahwa adanya penurunan kadar TLT pada wanita dewasa pegawai Dinas Kesehatan Yogyakarta yang overweight dan obesitas terjadi karena perlakuan pemberian ekstrak teh hijau. Hal ini didukung hasil recall 24 jam yang diperoleh pada waktu penelitian bahwa tidak terdapat perbedaan yang signifikan pada asupan zat gizi subjek antara awal dan akhir penelitian meskipun subjek tidak dikarantina yang memungkinkan subjek untuk mengonsumsi makanan apa saja bahkan mengonsumsi asupan zat gizi yang melebihi kebutuhan. Penurunan kadar TLT akibat perlakuan terjadi karena teh hijau memiliki daya hambat yang tinggi terhadap terjadinya oksidasi asam linoleat (asam lemak Omega 6). Tingginya daya penghambat ini disebabkan oleh adanya senyawa katekin dalam teh hijau yang merupakan komponen paling potensial dan secara kimiawi mempunyai aktivitas biologis yang paling kuat di antara senyawa katekin lainnya. Di samping itu, senyawa katekin diketahui bersinergi dengan asam askorbat dan asam sitrat (9). Dengan demikian, mengonsumsi teh hijau secara terus menerus akan menghambat persenyawaan lemak dalam tubuh sehingga TLT otomatis akan berkurang.

Katekin (EGCG) mempunyai efek hipokolesterolemik karena EGCG menekan absorpsi kolesterol di dalam usus. Asam lemak dioksidasi menjadi asetil KoA dan disintesis dari asetil-KoA. Jalur dan tempat yang dipakai untuk oksidasi asam lemak berlainan. Oksidasi asam lemak terjadi di dalam mitokondria. Asam lemak yang di luar mitokondria mengalami aktivasi dulu menjadi asil-KoA dan terjadi pemakaian energi yang menurunkan akumulasi trigliserida pada jaringan lemak $(6,7)$. Akibatnya, kadar total lemak tubuh menurun karena adanya penurunan akumulusi pada jaringan lemak.

Selain itu, katekin yang berhasil menghambat asetilKoA akan turut serta menurunkan kadar kolesterol dalam darah (hipokolesterolemik). Ini terjadi karena adanya sifat katekin yang mampu menghalangi penyerapan kolesterol di dalam usus (10). Di dalam sel usus halus, terdapat 2 monoasilgliserol yang akan disintesis menjadi triasilgliserol. Satu monoasilgliserol menjadi triasilgliserol. Triasilgliserol yang terbentuk dalam sel usus diserap masuk ke dalam pembuluh limfe dalam bentuk lipoprotein kilomikron. Hal ini sesuai dengan penelitian sebelumnya (6) tentang teh hijau yang juga membuktikan bahwa EGCG menghambat aktivitas asetil KoA dalam siklus biosintesis asam lemak sehingga dapat menurunkan akumulasi triasilgliserol (trigliserida) pada jaringan lemak.

Beberapa penelitian sebelumnya juga menyebutkan bahwa apabila penderita overweight dan obesitas diberi 
ekstrak teh hijau (ETH) yang mengandung katekin (EGCG), akan terjadi penghambatan enzim catechol-Omethyltransferase sehingga terjadi peningkatan aktivitas pada sistem saraf simpatik. Terjadinya peningkatan aktivitas pada sistem saraf simpatik akan menyebabkan peningkatan hormon katekolamin, epinefrin, norepinefrin, dan glukagon. Keempat hormon tersebut sangat berperan dalam peningkatan lipolisis (penguraian dan pencernaan lemak). Peningkatan lipolisis akan diikuti dengan peningkatan termogenesis (panas dalam tubuh untuk membakar lemak dan kalori) dan oksidasi asam lemak $(5,7,11,12)$. Dengan peningkatan oksidasi asam lemak, maka semakin banyak asetil-KoA yang dibentuk untuk menghasilkan energi. Dengan demikian, semakin sedikit simpanan lemak di jaringan adiposa. Proses lipolisis dan termogenesis inilah yang dapat menekan rasa lapar dan meningkatkan rasa kenyang yang akan berdampak pada status gizi dan selanjutnya status gizi ini akan mempengaruhi kondisi TLT dan profil lipid.

Lebih lanjut, penelitian di Swiss yang melibatkan pria muda (rerata berumur 25 tahun) sebagai sampel, melakukan pengukuran selama 24 jam terhadap jumlah pengeluaran energi pada orang yang diberi kafein $(50 \mathrm{mg}$ ), ekstrak teh hijau (50 mg kafein dan $90 \mathrm{mg}$ EGCG), serta plasebo. Hasil penelitian tersebut menunjukkan bahwa pemberian ekstrak teh hijau secara signifikan meningkatkan $4 \%$ jumlah pengeluaran energi dibandingkan plasebo. Diketahui bahwa teh hijau berpotensi sebagai termogenesis sehingga mampu meningkatkan pembakaran kalori dan lemak yang berimplikasi terhadap penurunan berat badan. Hasil studi ini menjanjikan potensi penggunaan ekstrak teh hijau dalam penurunan berat badan di samping melakukan pembatasan konsumsi kalori (diet) (5).

Hasil penelitian tersebut diperkuat dengan hasil penelitian pada hewan coba yang menunjukkan bahwa katekin teh dapat membantu melawan peningkatan obesitas. Peneliti Jepang membandingkan berat badan dan massa lemak pada tikus antara yang diberi pakan rendah lemak dan tinggi lemak, antara tikus yang berenang dan tidak, dan antara yang diberi katekin teh dan tidak. Tikustikus yang diberi pakan tinggi lemak dengan katekin teh tanpa olah raga menunjukkan pengurangan akumulasi lemak $14 \%$ sedangkan pada tikus yang berenang dan diberi katekin menunjukkan pengurangan akumulasi lemak hingga 33\% (Murase, et al., 2005).

\section{Penurunan profil lipid pada wanita dewasa overweight dan obesitas setelah perlakuan}

Hasil analisis menunjukkan tidak adanya penurunan yang signifikan kadar kolesterol antara sebelum dan setelah perlakuan. Namun demikian, hasil penelitian membuktikan adanya penurunan kolesterol pada kelompok kontrol dan kelompok perlakuan meskipun penurunan tersebut tidak signifikan secara statistik. Hal ini terjadi karena asupan zat gizi subjek tidak dikontrol selama penelitian. Selain itu, perbedaan aktivitas fisik subjek juga mempengaruhi hasil penelitian walaupun secara statistik aktivitas fisik bukan merupakan faktor pengganggu. Kemungkinan yang lain adalah penggunaan alat kontrasepsi hormon. Penggunaan alat kontrasepsi yang mengandung hormon estrogen dan progesteron menyebabkan gangguan metabolisme karbohidrat, lemak, dan lipoprotein yang dapat mempengaruhi proses pelepasan kolesterol. Selain itu, adanya komponen progestin dalam beberapa pil oral yang terkadang mempunyai efek androgenik di samping efek progestatisional, dapat menimbulkan efek yang kurang menguntungkan yaitu nafsu makan dan berat badan bertambah besar $(10,13)$.

Kenaikan kadar kolesterol di atas nilai normal diantaranya disebabkan oleh berlebihnya asupan makanan yang berasal dari lemak hewani, telur, dan makananmakanan yang dewasa ini biasa disebut sebagai makanan sampah (junk food). Di dalam junk food juga banyak terkandung sodium, lemak jenuh, dan kolesterol. Apabila zat-zat itu tertimbun banyak di dalam tubuh, maka akan menimbulkan penyakit, baik ringan maupun berat seperti darah tinggi, gangguan jantung, hingga kanker. Di sinilah peranan pemberian ekstrak teh hijau yang terlihat mampu mengendalikan dan menurunkan kadar kolesterol dalam darah. Dalam teh hijau terdapat katekin yang mengurangi penyerapan kolesterol di dalam usus sehingga orang yang mengonsumsi ekstrak teh hijau akan mendapatkan pengurangan penyerapan kolesterol secara terus menerus. Akibatnya, jelaslah bahwa kadar kolesterol dalam darah akan mengalami penurunan atau lebih rendah dibandingkan mereka yang tidak mengonsumsi ekstrak teh hijau tetapi penurunan tersebut tidak signifikan secara statistik. 
Demikian juga dengan kadar trigliserida dan kolesterol LDL yang menunjukkan tidak adanya perbedaan signifikan antara sebelum dan setelah perlakuan meskipun penurunan tetap terjadi tetapi tidak bermakna secara statistik. Apabila TLT mengalami penurunan seharusnya trigliserida juga menurun. Berbeda dengan hasil penelitian ini, penelitian sebelumnya menggunakan subjek penelitian yaitu anak-anak yang masih dalam perkembangan dan pertumbuhan sehingga korelasi TLT dan trigliserida dapat tergambar secara linear (1). Sementara itu, subjek penelitian ini adalah wanita dewasa yang tidak dalam masa perkembangan atau pertumbuhan. Penggunaan alat kontrasepsi yang mengandung hormon estrogen dan progesteron bisa juga menyebabkan gangguan metabolisme tubuh yang mempengaruhi proses penyerapan dan pelepasan trigliserida. Tingginya trigliserida sering disertai dengan keadaan kadar HDL rendah.

Trigliserida adalah asam-asam lemak dan merupakan jenis lemak yang paling banyak di dalam darah dengan ketentuan dianggap normal bila kadarnya kurang dari $150 \mathrm{mg} / \mathrm{dL}$. Trigliserida adalah bentuk utama lemak di dalam makanan. Setelah kita mengonsumsi makanan tinggi kalori, seperti sumber karbohidrat dan lemak, tubuh akan mengubahnya menjadi kalori. Penelitian sebelumnya membuktikan bahwa pemberian ekstrak teh hijau akan membantu meningkatkan pembakaran lemak, dalam arti meningkatkan metabolisme trigliserida untuk diubah menjadi asam lemak. Dengan demikian, setiap orang yang mengonsumsi ekstrak teh hijau secara rutin dan terus menerus akan mendapatkan pembakaran lemak yang maksimal. Hasil penelitian tersebut juga menyebutkan agar fungsi teh hijau sebagai fat burner lebih optimal, disarankan agar minum teh hijau sebelum latihan (14).

Disebutkan bahwa metabolisme tubuh pria berjalan lebih cepat daripada metabolisme tubuh wanita sehingga kolesterol LDL pada pria pun menurun lebih cepat dibandingkan pada wanita. Selain itu, penurunan LDL kemungkinan karena faktor endokrin yang berubah pada wanita yang sudah mengalami menopause. Kemungkinan yang lainnya, pada penelitian ini tidak dilakukan karantina terhadap subjek sehingga subjek dapat bebas mengonsumsi makanan. Dengan demikian, asupan zat gizi yang dikonsumsi tidak dapat dikontrol secara pasti sesuai tujuan penelitian.
Meskipun perlakuan diberikan ekstrak teh hijau, tetapi jika asupan zat gizinya berlebihan, tentu kadar kolesterol LDLnya pun tidak dapat turun secara signifikan.

Penelitian ini tidak menunjukkan penurunan LDL yang signifikan karena berbagai faktor lainnya, seperti aktivitas fisik, penggunaan kontrasepsi hormon, dan asupan gizi. Umur subjek penelitian pun secara tidak langsung mempengaruhi adanya penurunan kolesterol LDL sehingga tidak memperoleh perubahan yang signifikan secara statistik. Kolesterol LDL dikatakan kolesterol jahat karena LDL berperan membawa kolesterol ke sel dan jaringan tubuh. Bila jumlahnya berlebihan, kolesterol dapat menumpuk dan mengendap pada dinding pembuluh darah dan mengeras menjadi plak. Plak dibentuk dari unsur lemak, kolesterol, kalsium, produk sisa sel, dan materi-materi yang berperan dalam proses pembekuan darah $(9,13)$.

Berbeda dengan hasil analisis pada kadar kolesterol HDL yang menunjukkan adanya peningkatan signifikan antara sebelum dan setelah perlakuan. Harus diingat, bahwa perubahan yang diharapkan pada kolesterol HDL adalah peningkatan karena HDL merupakan kolesterol yang baik (7). HDL kolesterol adalah jenis kolesterol yang berperan membawa kolesterol jahat (kolesterol LDL) dari arteri kembali ke hati untuk pemrosesan lebih lanjut. HDL memiliki banyak protein, bertindak sebagai vacuum cleaner yang menghisap sebanyak mungkin kolesterol berlebih yang bisa diisapnya. HDL memungut kolesterol ekstra dari sel-sel dan jaringanjaringan lalu membawanya kembali ke hati. Kemudian organ hati mengambil kolesterol dari partikel HDL dan menggunakannya untuk membuat cairan empedu atau mendaur ulangnya. HDL merupakan kolesterol lipoprotein berkepadatan tinggi sehingga disebut sebagai kolesterol baik (13).

Penelitian sebelumnya menyatakan bahwa ada pengaruh pemberian katekin terhadap reduksi lemak tubuh dan hubungan antara oksidasi LDL dan variabel lemak tubuh. Hal ini menjadi dasar bahwa pemberian ekstrak teh hijau pada subjek penelitian ini akan menyebabkan reduksi lemak tubuh yang mempengaruhi keberadaan kolesterol HDL. Selama penelitian berlangsung, terjadi peningkatan asupan protein pada subjek penelitian. Protein merupakan salah satu sumber HDL kolesterol. 
Selain itu, dari data recall juga diketahui terjadi peningkatan asupan vitamin $\mathrm{C}$ dan vitamin $\mathrm{E}$. Kedua vitamin tersebut merupakan sumber antioksidan. Dapat dibayangkan bila dalam kondisi asupan protein, vitamin $\mathrm{C}$, dan vitamin $\mathrm{E}$ meningkat, para subjek penelitian tersebut juga diberikan ekstrak teh hijau yang merupakan sumber antioksidan terkuat (25-100 kali dari vitamin C dan vitamin E) yang diberikan terus menerus selama 90 hari, maka secara otomatis akan meningkatkan kadar kolesterol HDL $(5,6,10)$.

\section{SIMPULAN DAN SARAN}

Efek pemberian ekstrak teh hijau pada wanita dewasa pegawai Dinas Kesehatan Kota Yogyakarta yang mengalami overweight dan obesitas dapat menurunkan total lemak tubuh (TLT) secara signifikan pada kelompok perlakuan sedangkan pada kelompok kontrol justru terjadi peningkatan TLT. Di samping itu, ekstrak teh hijau juga dapat mengubah profil lipid yaitu penurunan kolestoral total, penurunan trigliserida, penurunan LDL, dan peningkatan HDL. Namun, hanya perubahan kolesterol HDL yang mengalami peningkatan signifikan pada kelompok perlakuan dan jumlahnya cukup besar dibandingkan yang tidak mendapatkan perlakuan.

Perlu adanya konsultasi gizi bagi pegawai wanita di Dinas Kesehatan Kota Yogyakarta, serta kegiatan atau olahraga yang diadakan secara rutin dalam jangka waktu tertentu. Bagi masyarakat umum, perlu menjaga pola makan, kegiatan atau aktivitas fisik, dan mengonsumsi teh hijau secara rutin untuk menjaga berat badan dan profil lipid.

\section{RUJUKAN}

1. Suarca K, Suandi IKG. Hubungan antara total lemak tubuh dengan profil lipid pada anak obese di SD Denpasar. Cermin Dalam Kedokteran 2007;34(6):159.

2. Departemen Kesehatan RI. Aktivitas fisik dan diet seimbang mencegah kanker. [series online] 2007 [cited 2012 Jan 20]. Available from: URL: http://www.depkes. go.id/index.php/berita/press-release/170-aktivitas-fisikdan-diet-seimbang-mencegah-kanker.html

3. Van Itallie TB. Health implications of overweight and obesity in the United States. Ann Intern Med [series online] 1985 Dec [cited 2012 Jan 20];103(6 Pt 2):983-8. Available from: URL: http://www.annals.org/content/103/6 Part_2/983.abstract

4. Ogden CL, Carroll MD. Prevalence of overweight, obesity, and extreme obesity among adults: United States, trends 1960-1962 through 2007-2008. [series online] 2010 Jun [cited 2012 Jan 20]. Available from: URL: http://www. cdc.gov/nchs/data/hestat/obesity_adult_07_08/obesity_ adult_07_08.pdf

5. Dulloo AG, Duret C, Rohrer D, Girardier L, Mensi N, Fathi M, Chantre P, Vandermander J. Efficacy of a green tea extract rich in catechin polyphenols and caffeine in increasing 24-h energy expenditure and fat oxydation in humans. Am J Clin Nutr 1999;70(6):1040-5.

6. Dewi K. Pengaruh ekstrak teh hijau (Camellia sinensis var. Assamica) terhadap penurunan berat badan, kadar trigliserida dan kolesterol total pada tikus jantan Galur Wistar. Jurnal Kesehatan Masyarakat 2008;7(2):156-63.

7. Nagao T, Komine Y, Soga S, Meguro S, Hase T, Tanaka $\mathrm{Y}$, Tokimitsu I. Ingestion of a tea rich in catechins leads to a reduction in body fat and malondialdehyde-modified LDL in men. Am J Clin Nutr 2005;81(1):122-9.

8. Archer KJ, Lemeshow S, Hosmer DW. Goodness of fit test for logistic regression models when data are collected using a complex sampling design. Comput Stat Data Anal 2007;51(9):4450-64.

9. Venables MC, Hulston CJ, Cox HR, Jeukendrup AE. Green tea extract ingestion, fat oxidation, and glucose tolerance in healthy humans. Am J Clin Nutr 2008;87(3):778-84.

10. Kovacs EM, Mela DJ. Metabolically active functional food ingredients for weight control. Obes Rev 2006;7(1):59-78.

11. Belza A, Toubro S, Astrup A. The effect of caffeine, green tea and tyrosine on thermogenesis and energy intake. Eur J Clin Nutr 2009;63:57-64.

12. Junge C, Freeman MW. Kolesterol rendah jantung sehat. Jakarta: Buana Ilmu Populer; 2005.

13. Toruan PL. Fat-loss not weight-loss: gemuk tapi ramping. Jakarta: TransMedia; 2008.

14. Rohdiana D, Raharjo S, Gardjito M. Evaluasi daya hambat tablet effervescent teh hijau pada oksidasi asam linoleat. Majalah Farmasi Indonesia 2005;16(2):76-80. 